\title{
Effects of proanthocyanidins on digestion of fiber in forages
}

\author{
JESS D. REED
}

Author is associate professor, Department of Animal Sciences, University of Wisconsin-Madison, Madison, Wisc. 93706.

\begin{abstract}
The ability of proanthocyanidins (PA) to form insoluble complexes with proteins and polysaccharides affects fiber digestion and analysis. This review discusses these effects in relationship to the application of the detergent system of forage analysis. A fraction of the PA in plants remains after extraction for analysis. Insoluble PA may be a natural part of the plant cell wall or may be insoluble because of high molecular weight and post harvest reactions. These reactions increase the amount of insoluble $\mathrm{PA}$ and decrease the amount of soluble PA. The butanol-HCl assay is the most suitable method for analysis of insoluble PA. Insoluble PA are associated with negative apparent digestion coefficients for acid-detergent lignin (ADL), neutral-detergent insoluble $\mathrm{N}$ and acid-detergent insoluble $\mathbf{N}$. The addition of sodium sulfite to neutral detergent eliminates insoluble PA from NDF. However, the addition of sodium sulfite to neutral detergent will give misleading results in relationship to true digestibility of protein. The difference between fiber fractions that are prepared with and without the addition of sodium sulfite to neutral-detergent may estimate the amount of PA/protein complex associated with NDF. A better understanding of the relationship between PA structure and function is necessary to manipulate PA in forages through breeding or genetic engineering. The interaction between $P A$ and fiber analysis and digestion is an important component of this research.
\end{abstract}

Key Words: condensed tannins, neutral detergent, acid detergent, lignin, polyphenolics

Proanthocyanidins (PA) are naturally occurring plant polyphenols that strongly influence the nutritive value of forages. In general, PA and condensed tannins are synonyms. Phytochemists prefer to use proanthocyanidin because, as discussed below, this term is more closely related to their chemical structure. Most nutritionists use "condensed tannins" because tannins are defined as water-soluble polymeric phenolics that precipitate proteins (Haslam 1989). However, many soluble phenolics that have structural and chemical properties that are similar to PA do not precipitate proteins. There are also high molecular weight PA that have structures related to tannins but that are not water-soluble (Bate-Smith 1973, Stafford and Cheng 1980).

Proanthocyanidins in forages have both negative and positive effects on nutritive value (Reed et al. 1990, Mueller-Harvey and McAllan 1992). In high concentrations, PA reduce intake, digestibility of protein and carbohydrates, and animal performance (Barry and Duncan 1984, Reed et al. 1990). In low to moderate concentrations, PA prevent bloat and increase the flow of non-ammonia nitrogen and essential amino acids from the rumen (Egan and Ulyatt 1980, Barry and Manley 1984, Waghorn

\footnotetext{
Manuscript accepted 25 Nov. 00.
}

\section{Resumen}

La capacidad de las proantocianidinas (PA) para formar complejos insolubles con proteínas y polisacáridos afectan la digestión de la fibra y su análisis. Esta revisión discute estos efectos en relación a la aplicación del sistema de detergente del análisis de forrajes. Una fracción de las PA en las plantas permanecen después de la extracción para el análisis. Las PA insolubles pueden ser una parte natural de la pared celular de la planta o pueden ser insolubles debido al alto peso molecular y reacciones post-cosecha. Estas reacciones aumentan la cantidad de PA insoluble y disminuyen la cantidad de PA soluble. El método de Butanol-HCL es el mas apropiados para el análisis de PA insolubles. Las PA insolubles son asociadas con coeficientes negativos de digestión aparente de la lignina acido detergente (ADL), $\mathbf{N}$ insoluble neutro detergente $\mathbf{y} \mathbf{N}$ insoluble acido detergente. La adición de sulfito de sodio a 1 detergente neutro elimina las PA insolubles de la NDF. Sin embargo, la adición de sulfito de sodio al detergente neutro producirá resultados erróneos en relación a la digestibilidad verdadera de la proteína. La diferencia entre las fracciones de fibra que son preparadas con y sin la adición de sulfito de sodio al detergente neutro pueden estimar la cantidad del complejo PA/proteína asociado con la NDF. Se necesita un mejor entendimiento de la relación entre la estructura y función de las PA para manipular las PA en los forrajes a través del mejoramiento o ingeniería genética. La interacción entre las PA,el análisis de fibra y la digestión es un componente importante de esta investigación.

et al. 1987, McNabb et al. 1993). The positive effects of tannins on protein utilization have practical importance because problems associated with extensive proteolysis and (or) deamination in the rumen limit production in modern feeding systems (Beever et al. 1989). Proanthocyanidins may also protect ruminants against helminthiasis. Undrenched lambs grazing sulla (Hedysarum coronarium L.), a forage that contains PA, had lower fecal egg counts and Trichostrongylus colubriformis worm burdens and higher average daily gains than undrenched lambs grazing alfalfa (Medicago sativa L.), which does not contain PA (Niezen et al. 1995). Several useful reviews on the nutritional effects of PA and tannins in the diets of ruminants have been written in recent years (MuellerHarvey and McAllan 1992, Reed 1995, Waghorn et al. 1999).

Research on the relationship between concentration of PA in forages and parameters of nutritive value is complicated by inadequate methodology for quantification and structural analysis. The ability of PA to form strong complexes with proteins is the most important aspect of their nutritional and toxic effects (Hagerman and Butler 1981). The strength of these complexes depends on characteristics of the PA and protein (molecular weight, tertiary structure, isoelectric point, and compatibility of binding sites). Proanthocyanidins have a large number of free phenolic hydroxyl groups that form strong hydrogen bonds with 
proteins and carbohydrates (Haslam 1989). Proanthocyanidins also complex with proteins through hydrophobic bonding (Oh et al. 1980). In addition, PA form covalent bonds with proteins through oxidative polymerization reactions as a result of heating, exposure to ultraviolet radiation and the action of polyphenol oxidase (Haslam 1989). The ability of PA to form insoluble complexes with proteins and polysaccharides leads to several effects on fiber digestion and analysis. This review discusses these effects in relationship to the application of the detergent system of forage analysis.

\section{Chemistry and Nomenclature of Proanthocyanidins}

Proanthocyanidins are polymers that belong to the class of secondary plant compounds known as flavonoids (Harborne 1994, Haslam 1989, Stafford 1990, Foo et al 1982). Monomeric and polymeric flavonoids are ubiquitous in higher land plants and have many ecological and nutritional effects on animals (Harborne 1993). The principal structure of PA is based on repeating units of polyhydroxy flavan units linked by $\mathrm{C}$ bonds between carbons 4 and 8 of the ring structures (Fig. 1). These covalent bonds are resistant to hydrolysis and no known enzyme is capable of cleaving the interflavan bond.

However, PA undergo a cleavage reaction upon heating with strong acids. This reaction is an auto-oxidation to form an intermediate that undergoes oxidation to an anthocyanidin. The term proanthocyanidin (PA) is prefered over condensed tannin because their discovery and distribution in plants was determined by this characteristic auto-oxidation reaction. Therefore, PA are defined as colorless plant compounds that form anthocyanidins upon heating in solutions of strong acids. Specific names for PA are given based on the type of anthocyanidin formed during the autoxidation reaction. Proanthocyanidins that yield cyanidin are termed procyanidins and those that yield delphinidin are termed prodelphinidin (Fig. 2). These 2 PA are the most common but many diverse PA occur in plants including propelargonidin and proluteolinidin. One problem with this nomenclature is that it implies that the proanthocyanidins are homopolymers. However, as we learn more about the structure of PA it is clear that many heteropolymers occur in nature. Proanthocyanidins have been described

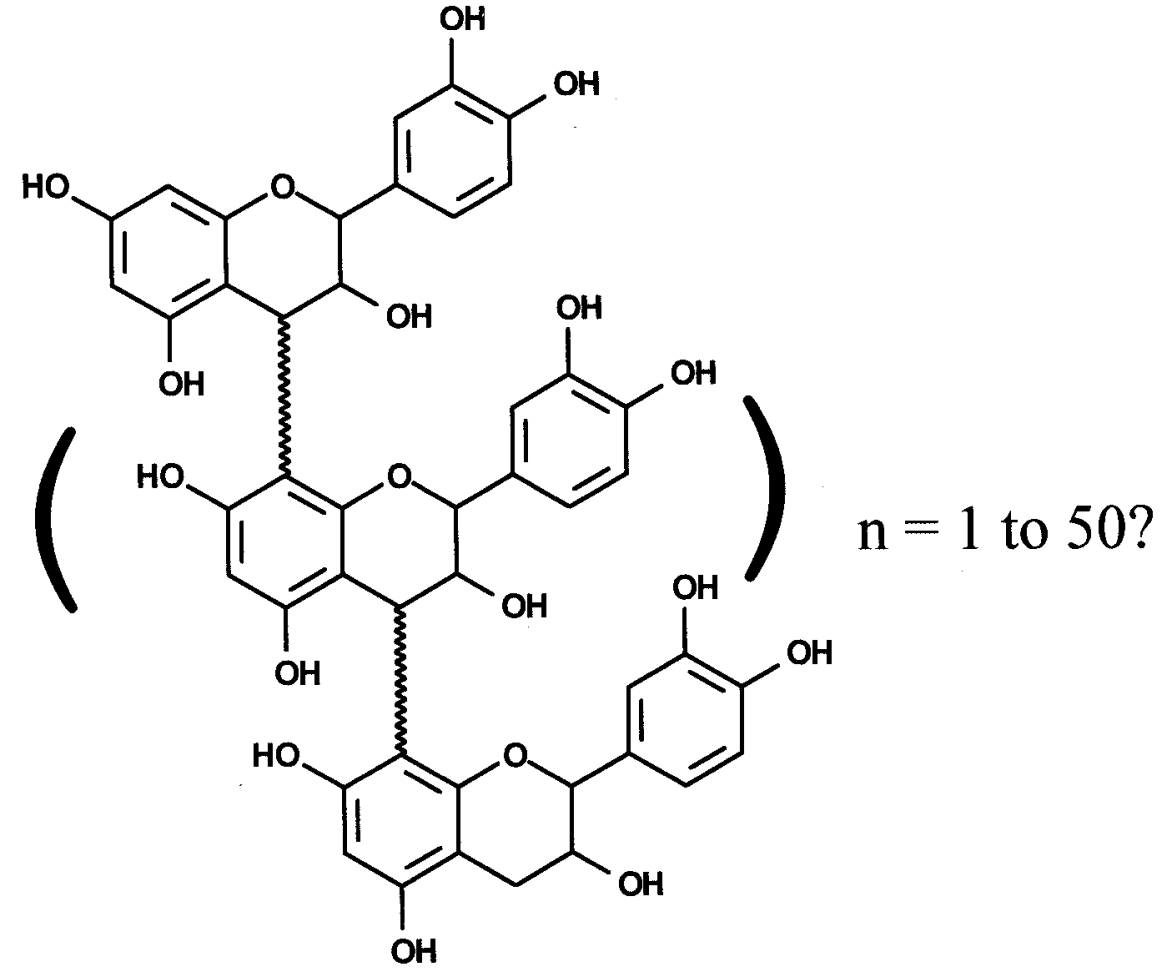

Fig. 1. Structure of proanthocyanidin polymers.

with glycosylation, acylation with gallic acid, and other substitutions (Porter 1994).

The solubility and extraction of PA in forage legumes were initially studied by Bate-Smith (1973). This research demonstrated that substantial amounts of PA are not extracted by aqueous organic solvents and remain in the fibrous residue after extraction. The origin of these insoluble $\mathrm{PA}$ remains somewhat controversial. Haslam (1989) proposed that PA are a natural part of the plant cell wall with covalent bonds to cell wall polysaccharides. On the other hand Stafford (1988) suggests that PA are insoluble because of high molecular weight and post harvest condensation reactions with proteins and cell wall polysaccharides. Regardless of the mechanism, a fraction of the PA in most plants remains after extraction for analysis. This fraction has a large effect on the analysis of fiber and its relationship to nutritive value and is the main topic of this paper.

Table 1. Extractable and insoluble proanthocyanidins (PA) in leaves from Sesbania sesban and $S$. goetzei and their interspecific crosses.

\begin{tabular}{lcc}
\hline \hline Species & Extractable PA & Insoluble PA \\
\hline & $\left(\mathrm{A}_{550}\right)^{1}$ & $\left(\mathrm{~A}_{550}\right)^{2}$ \\
S. sesban & 0.503 & 0.263 \\
S. goetzei & 0.556 & 0.727 \\
S. sesban x S. goetzei & 0.928 & 0.821 \\
S. goetzei $\mathrm{x}$ S. sesban & 0.807 & 1.029 \\
\hline
\end{tabular}

Absorbance at $550 \mathrm{~nm}$ from the butanol- $\mathrm{HCl}$ reaction of the extract of $100 \mathrm{mg}$ of DM in $15 \mathrm{ml}$ of aqueous acetone. ${ }^{2}$ Absorbance at $550 \mathrm{~nm}$ from the butanol $\mathrm{HCl}$ reaction on $5 \mathrm{mg}$ of neutral-detergent fiber. 
<smiles>[R]c1cc(C2Oc3c(c(O)cc(O)c3C3c4c(O)cc(O)cc4OC(c4cc([R])c(O)c(O)c4)C3O)CC2O)cc(O)c1O</smiles>

$$
\begin{aligned}
& \text { Proanthocyanidin dimer } \\
& \mathrm{R}=\mathrm{H} \text {, Procyanidin } \\
& \mathrm{R}=\mathrm{OH} \text {, Prodelphinidin }
\end{aligned}
$$<smiles>[R]c1cc(C2C(O)Cc3c(O)cc(O)cc3OC2c2cc([R])c(-c3[o+]c4cc(O)cc(O)c4cc3O)c(O)c2)cc(O)c1O</smiles>

Athocyanidin+Flavan-3-ol
$\mathrm{R}=\mathrm{H}$, Cyanidin + Catechin
$\mathrm{R}=\mathrm{OH}$, Delphinidin + Gallocatechin

Fig. 2. Butanol-HCl reaction of proanthocyanidins.

\section{Analytical Methods}

The quantification of PA in plants is essential to studies on their nutritional and ecological effects (Feeny and Bostock 1968, Swain 1979, Horvath 1981, Martin and Martin 1982, Waterman and Mole 1994). However, the commonly used methods of colorimetric analysis have many problems (Tempel 1982, Martin and Martin 1982). There are a growing number of analytical methods for the determination of PA in plants (Waterman and Mole 1994). However, no single method will give satisfactory results for quantitative analysis in relationship to nutritional effects because the chemical properties that are involved in the reactivity of PA in colorimetric and (or) precipitation assays differ from the properties that underlie their nutritional or toxic effect. Animal species also differ in nutritional response ingesting plants that contain PA (Hagerman et al. 1992). Sample preparation also has a large influence on the determination of PA and related polyphenols in plants. Proanthocyanidins in fresh samples are likely to have low complex formation and oxidative polymerization and high solubility in aqueous organic solvents. If storage is necessary, freezing is preferred over other methods as long as the samples are not allowed to thaw before extraction (Mould and Robbins 1981). In some situations, drying is the only means of preserving material. At low temperatures $\left(<40^{\circ} \mathrm{C}\right)$, enzymes may still function leading to oxidation. At temperatures above $60^{\circ} \mathrm{C}$, heat damage and polymerization may occur (Haslam 1966). These post harvest reactions increase the amount of insoluble PA and decrease the amount of soluble PA. If the researcher does not attempt to assay for insoluble PA then the total amount will be severely underestimated in the case of oven drying.

The most commonly used colorimetric procedures for the analysis of PA are the the vanillin- $\mathrm{HCl}$ reaction (Broadhurst and Jones 1978) and the butanol- $\mathrm{HCl}$ reaction (Bate-Smith 1973, 1975). The vanillin$\mathrm{HCl}$ reagent is specific for flavan-3-ols and proanthocyanidins. The reaction is based on the condensation of the phenolic aldehyde (vanillin) with the phloroglucinol structure of flavan-3-ols and proanthocyanidins under acidic conditions in methanol or ethanol. The butanol-HCl reaction is specific to the proanthocyanidins and is the prefered method because of its close relationship to the accepted nomenclature. The butanol-HCl method can also be applied to insoluble PA by placing the fibrous residues after extraction into the solution. After heating, the red pigments formed during the auto-oxidation reaction go into solution.

These colorimetric procedures share the analytical problem of lack of suitable standards. The most commonly used standards are catechin for the vanillin- $\mathrm{HCl}$ reaction and quebracho tannins for the butanol- $\mathrm{HCl}$ reaction. However, the extinction coefficients for the chromophores produced in the reaction with these standards usually are different than the compounds from the plant extracts. This difference can lead to large under and over estimations of the content of PA and is probably the single largest cause for the great deviation in concentrations that are reported in the literature (Giner-Chavez et al. 1997). Another problem is that the mechanism that leads to the reaction of PA with the analytical reagent is unrelated to the mechanism underlying their nutritional effects (Reed 1995). The most suitable method is to use the butanol- $\mathrm{HCl}$ assay and isolate the PA from the plant species under investigation for use as a standard. Reversible adsorption of PA from plant extracts onto Sephadex LH-20 is a commonly used method for isolating PA from plants (Hagerman 1991, Giner-Chavez et al. 1997). Reed et al. (1985) developed a gravimetric method based on the ability of trivalent ytterbium to selectively precipitate PA from plant extracts. The advantage of $\mathrm{Yb}$ precipitation is that the precipitate can be easily dissolved to yield a solution of the PA. These solutions are used for colorimetric analysis (Giner-Chavez et al. 1997), chromatography, enzyme inhibition studies and in vitro and in vivo assays for inhibition (Reed et al. 1985). The results from the assays on the dissolved PA also relate to an equivalent weight of PA precipitate. The 2 methods for isolating PA give similar results for several species of forages (Giner-Chavez et al. 1997). 


\section{Effects of Proanthocyanidins on Fiber Analysis}

The extraction of PA from plant samples is a problem that is often overlooked in PA analysis. Bate-Smith (1973) showed that, in sainfoin (Onobrychis viciaefolia), a significant percentage of the PA is not extracted by aqueous organic solvents. The extraction is improved by fine milling and using hot methanol, but there is always a substantial amount of PA which remains in the fibrous residue after extraction. High molecular weight PA may be completely insoluble in aqueous organic solvents (Stafford and Cheng 1980).

Much of the PA remains in the neutraldetergent fiber (NDF) after sequential extraction of several browse species with aqueous acetone $\left(7: 3\right.$, acetone: $\left.\mathrm{H}_{2} \mathrm{O}\right)$ followed by neutral detergent (Reed et al. 1982, Reed 1986). This problem is common in several types of feeds that contain PA (Terrill et al. 1992). Insoluble PA in the NDF of sorghum grain was inversely correlated with soluble PA $(r=-.69, p<$ $.01, \mathrm{n}=16)$ in brown and red varieties (Reed 1987). These results suggest that analysis of extractable PA may underestimate the total PA content in many samples.

The amount of PA in the fiber fractions can be estimated by using the butanol- $\mathrm{HCl}$ assay (Bate-Smith 1973, Reed et al. 1982, Terrill et al. 1992). The nutritional effects of the insoluble PA have not been adequately studied. They are associated with negative apparent digestion coefficients for acid-detergent lignin (ADL), neutraldetergent insoluble $\mathrm{N}$ and acid-detergent insoluble $\mathrm{N}$ in browse legumes (Reed et al. 1990, Wiegand et al. 1995). Increased total fecal excretion and increased fecal excretion of water, fat, and nitrogen were observed in rats fed carob pod concentrate that contained non-extractable condensed tannins (Bravo et al. 1993).

Terrill et al. (1992) developed a method to determine the extractable PA, proteinbound PA and fiber-bound PA in forages and protein concentrate meals. The method uses a modified butanol- $\mathrm{HCl}$ procedure. Protein-bound PA in the fiber remaining after extraction with aqueous acetone is extracted with a solution of sodium dodecyl sulphate (SDS) and 2mercaptoethanol. The fiber-bound PA is determined directly on the residue after extraction with SDS. The ratio of extractable PA to protein-bound PA to fiber-bound PA was highly variable among these feeds but in each case the fiber-bound fraction was the lowest (Table 2). Similar results were obtained for tropi-

Table 2. Extractable, protein-bound and fiber-bound proanthocyanidins in species of forages.

\begin{tabular}{lccc}
\hline \hline Source and Species & Extractable & Protein-bound & Fiber-Bound \\
\hline Terrill et al 1992: & & & 14 \\
$\quad$ Lotus pedunculatus & 59 & 13 & 1 \\
Lotus corniculatus & 7 & 13 & 1 \\
Hedysarum coronarium & 23 & 10 to 28 & 4 to 8 \\
Jackson et al 1996: & 103 to 158 & 6 to 98 & 3 to 32 \\
Calliandra calothyrsus & 19 to 1981 & 16 to 30 & 8 to 10 \\
Flemingia macrophylla & 82 to 197 & & \\
Desmodium ovalifolium & & 4 to 35 & 2 to 10 \\
Giner-Chavez et al 1997: & 63 to 2721 & 21 to 120 & 0 to 1 \\
Desmodium ovalifolium & 0 to 43 & 12 to 22 & \\
Gliricidia sepium & 22 to 126 & & \\
Manihot esculenta & &
\end{tabular}

cal tree, shrub and forage legumes by using this method (Jackson et al. 1996). Similar results were also obtained by Giner-Chavez et al. (1997) by using a different methodology. Gliricidia sepium had the highest proportion of protein-bound and fiber-bound PA in the studies of Jackson et al. (1996) and Giner-Chavez et al. (1997).

The assumption in the butanol $\mathrm{HCl}$ reaction of the insoluble and fiber bound PA is that the stoichiometry of the reaction is identical to the extractable PA that was isolated from the plant species for use as a standard. This is unlikely to be the case. The butanol $\mathrm{HCl}$ reactivity for the fiber bound PA is likely to be much lower than the extractable PA that was used as a standard. The formation of an insoluble complex between PA and protein or polysaccharide is likely to decrease the reactivity of the PA in the auto-oxidation reaction that occurs in the butanol $\mathrm{HCl}$ reagent. This difference in reactivity would lead to an underestimation of the amount of fiberbound PA.

Table 3. Soluble and insoluble proanthocyanidins and digestibility of acid-detergent lignin (ADL) by rams in 3 accessions of Sesbania sesban $(10865,15019$, and 15036) and 1 accession of $S$. goetzei (15007). Rams were supplemented with leaves from $S$. sesban or $S$. goetzei to supply 3 levels of crude protein.

\begin{tabular}{lllll}
\hline \hline & & \multicolumn{2}{c}{ Sesbania accession } \\
& 10865 & 15019 & 15036 & 15007 \\
\hline Soluble PAs & & & & \\
$\left(\right.$ A $_{550} / g$ DM) & 13 & 35 & 93 & 95 \\
Insoluble PAs & 24 & 48 & 71 & 271 \\
$\left(\right.$ A $_{550} / \mathrm{g}$ DM) & & & & \\
\hline
\end{tabular}

\section{Level of CP from}

Sesbania (g/day)

$\begin{array}{lccc}25 & -26.8 & -69.3 \\ 50 & 15.1 & -40.2 & -95.2 \\ 75 & 7.1 & -46.1 & -110.7 \\ \text { mean } & 11.2 & -37.7 & -91.7\end{array}$

mean

${ }^{1}$ Values for proanthocyanidins were determined by analysis with butanol- $\mathrm{HCl}$ and expressed as absorbance units per $\mathrm{g}$ of dry matter analyzed. 
$\mathrm{HCl}$ analysis of feed and digesta. The reactivity of PA in butanol- $\mathrm{HCl}$ is most likely altered in the process of digestion. This change in reactivity may be related to the increase in ADL and detergent insoluble nitrogen fractions of digesta and feces that is observed in ruminants fed forages that contain PA (Reed et al. 1990, Yocum and Reed 1994, Yocum 1995, Wiegand et al. 1995).

\section{Proanthocyanidins and the Detergent System of Forage Analysis}

Research on the use of 3 accessions of Sesbania sesban and 1 accession of $S$. goetzei as sources of protein in diets for sheep demonstrated the effects of PA on the application of the detergent system of forage analysis (Wiegand et al. 1995). Accessions with a high content of PA had negative digestion coefficients for neutraldetergent insoluble nitrogen (NDIN) and acid-detergent lignin (ADL) (Table 3). Higher amounts of ADL and NDIN excreted in the feces than consumed are a result of the formation of these fractions in the digestive tract. The origin of the NDIN in the feces may be from dietary or endogenous sources. Reed et al. (1990) also observed negative digestion coefficients for NDIN in sheep fed diets containing forage from 2 tree species, Acacia cyanophylla and $A$. sieberiana DC., that had high levels of PA.

Linear regression of the apparent digestible amount of $\mathrm{N}$ and the amount of $\mathrm{N}$ in the diet can estimate true digestibility of nitrogen. Uniform feed fractions have a constant true digestibility and the metabolic amount in the feces is estimated by the intercept of this linear regression. The slope of this regression in forages that do not contain PA is approximately 0.88 and indicates that the forage $\mathrm{N}$ has uniform nutritional availability and high true digestibility (Van Soest 1967). The negative intercept is an estimate of $\mathrm{N}$ of endogenous origin and is approximately $0.5 \%$ of dry matter intake. The slope and intercept of the regression analysis for the accession of $S$. sesban with the lowest content of PA were similar to the expected values. The high $\mathrm{r}^{2}$ and low standard error indicates that the $\mathrm{N}$ in this accession was digested in a nutritionally uniform manner. The lower slope and $r^{2}$ and higher standard error for the regression analysis of accessions that contained higher levels of PA indicated that the $\mathrm{N}$ in these acces-

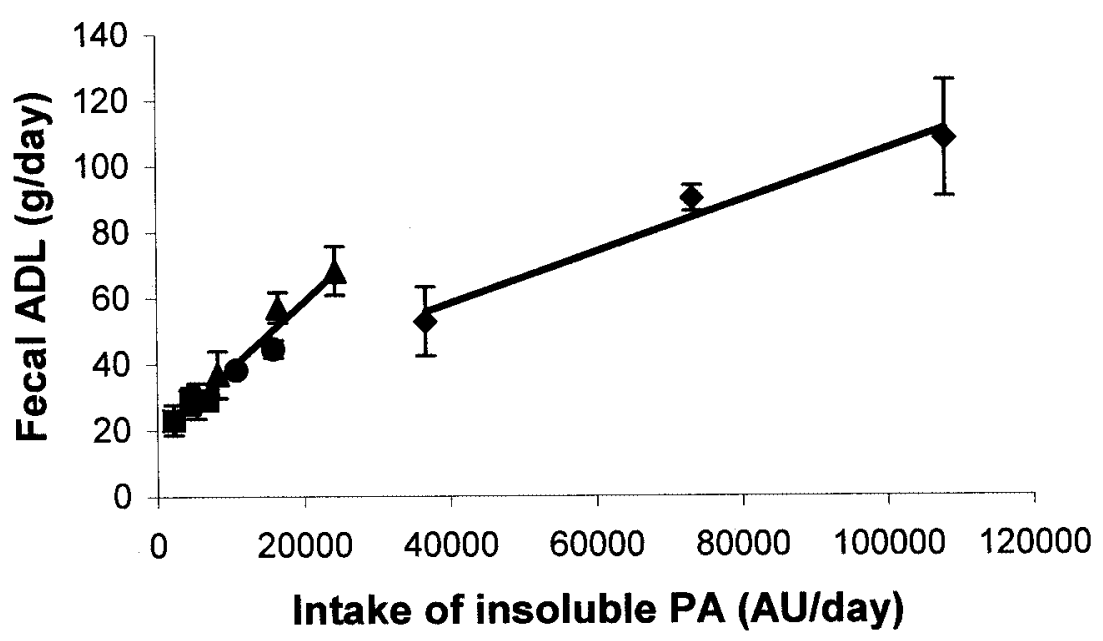

Fig. 3. Excretion of acid-detergent lignin (ADL) and intake of insoluble proanthocyanidins (PA) in sheep fed 3 accessions of Sesbania sesban (10865, squares; 15019, circles; and 15036, triangles) and 1 accession of $S$. goetzii (15007, diamonds) at 3 levels of crude protein offered from each accession. sions was not digested in a nutritionally uniform manner. These results indicate that, as the level of PA increase, forage $\mathrm{N}$ becomes nutritionally non-uniform and true digestibility of $\mathrm{N}$ can not be predicted by regression analysis. Similar effects of PA on true digestibility of $\mathrm{N}$ were observed for Acacia cyanophylla, A. sieberiana and $A$. seyal Del. that contained high levels of PA (Reed et al. 1990).
The increased excretion of fecal NDIN and negative digestion coefficients also indicates that the $\mathrm{N}$ in the sesbania accessions that contain high levels of PA is digested in a nutritionally non-uniform manner. Fecal excretion of NDIN was highly correlated to intake of insoluble PA. These results indicate that PA cause the formation of detergent insoluble complexes in the digestive tract. Intake of PA

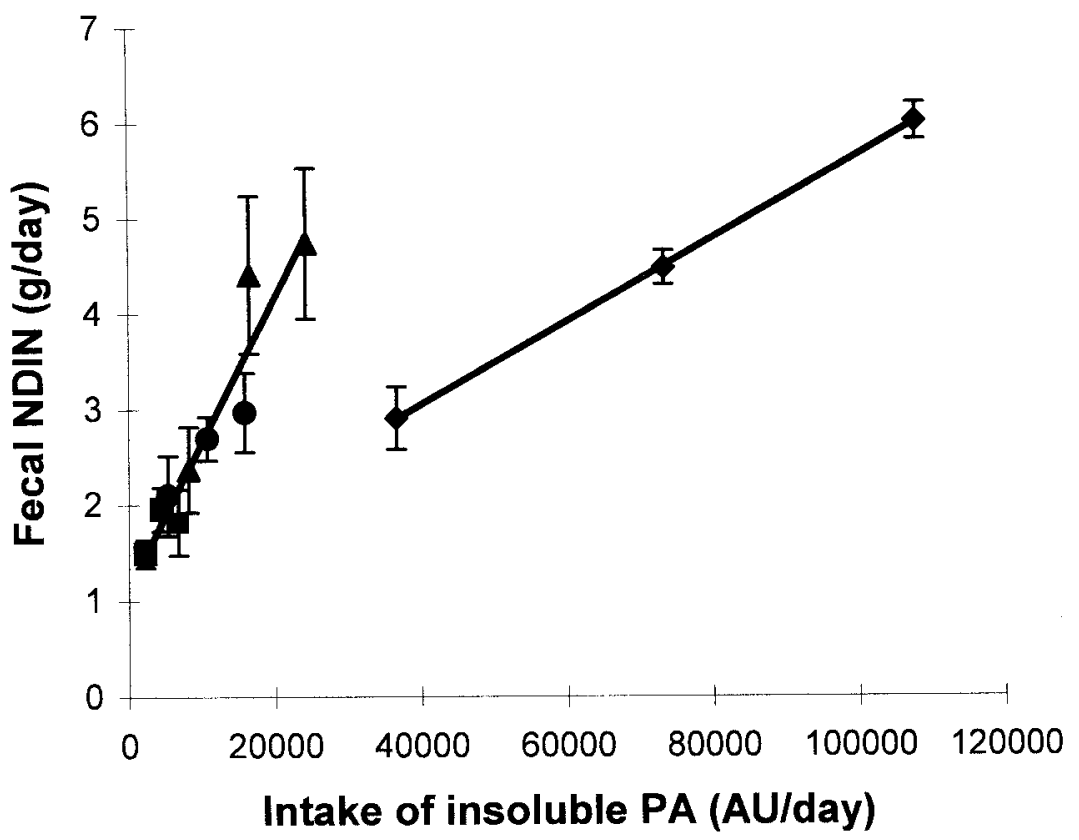

Fig. 4. Excretion of neutral-detergent-insoluble N (NDIN) and intake of insoluble proanthocyanidins (PA) in sheep fed 3 accessions of Sesbania sesban (10865, squares; 15019, circles; and 15036, triangles) and 1 accession of $S$. goetzii (15007, diamonds) at 3 levels of crude protein offered from each accession. 
Table 4. Insoluble PA (A550 $\left.\mathrm{g}^{-1}\right)$ with (+) and without (-) addition of sodium sulfite to neutral detergent (Krueger et al 1999).

\begin{tabular}{lccc}
\hline \hline & \multicolumn{3}{c}{$\begin{array}{c}\text { Neutral Detergent Insoluble } \\
\text { Proanthocyanidin }\end{array}$} \\
& & Sulfite Trt. & Difference \\
\hline Sericea (AU Donnely) & 130 & $(\mathrm{~g} / \mathrm{kg})$ & 129 \\
Sericea (Serala) & 216 & 1 & 215 \\
Crownvetch & 38 & 2 & 36 \\
Sainfoin (Eski) & 36 & 2 & 33 \\
Sainfoin (Remont) & 27 & 3 & 24 \\
Birdsfoot trefoil (Viking) & 21 & 2 & 19 \\
Birdsfoot trefoil (Norcen) & 17 & 1 & 16 \\
\hline
\end{tabular}

was highly correlated to fecal excretion of ADL and NDIN, and fecal ADL and NDIN were also highly correlated.

Proanthocyanidins cause the formation of detergent insoluble complexes that elevate fecal excretion of NDIN and ADL. The formation of these complexes violates 2 of the basic principles of the application of detergent analysis for estimating the nutritive value of forages. The first principle is that neutral-detergent solubles and crude protein are nutritionally uniform and have high true digestibility. The second is that fiber fractions are of plant origin and cannot originate in the digestive tract (Van Soest 1967). The violation of these principles in forages that contain PA does not invalidate the use of the detergent system of analysis. These results suggest that the deviation from ideal behavior in the deter-
(Astragalus cicer L.), sericea lespedeza [Lespedeza cuneata (Dum.-Cours) G. Don], and kura clover (Trifolium ambiguum M. Bieb. ) were subjected to sequential detergent fiber analysis to investigate the effects that the addition of $0.5 \mathrm{~g}$ sodium sulfite to neutral detergent has on the recovery and composition of fiber and lignin from forage legumes that vary in levels of PA (Krueger et al. 1999). Soluble, insoluble, and neutral detergent insoluble PA (NDIPA) concentrations were highest in sericea, moderate in crownvetch, sainfoin, and birdsfoot trefoil and absent in alfalfa, cicer milkvetch, red clover, and kura clover. Addition of sodium sulfite reduced levels of neutral detergent fiber (NDF), acid detergent fiber (ADF), acid detergent lignin (ADL), neutral detergent insoluble nitrogen (NDIN), and acid detergent insoluble nitrogen (ADIN) recovered from most forages tested. The addition of sodium sulfite effectively eliminated NDIPA from NDF (Table 4). The difference between fiber fractions prepared without and with the addition of sodium sulfite during the neutral detergent procedure was related to PA concentration. Neutral detergent fiber difference was positively correlated with insoluble PA $(\mathrm{r}=$ $0.905, p=0.0001)$ and NDIPA $(r=0.913$, $\mathrm{p}=0.0001 ;$ Fig. 5 ). The addition of sodium sulfite to neutral detergent in sequential detergent analysis of PA containing species eliminates the insoluble PA frac-

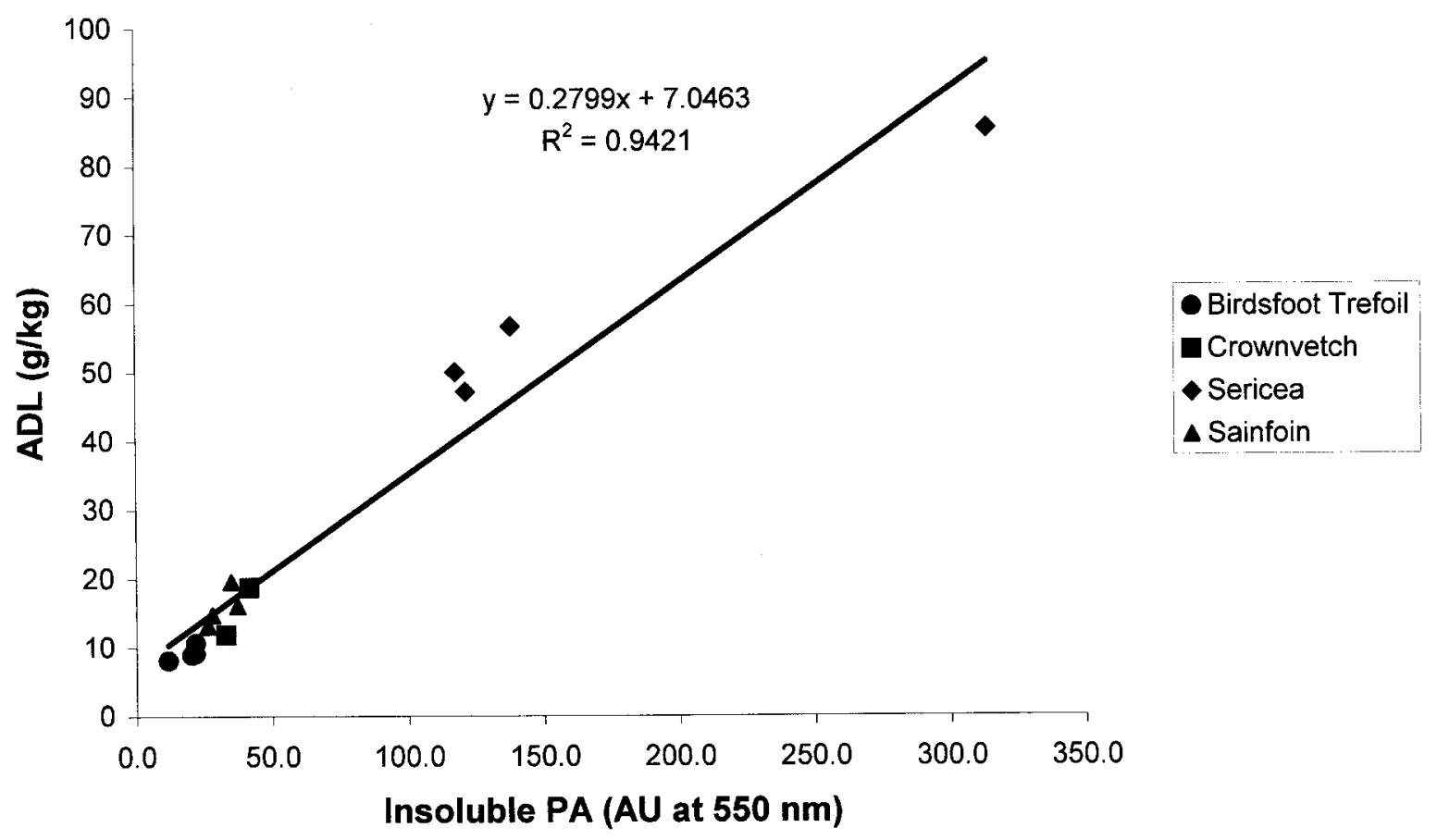

Fig. 5. Difference in sequential acid-detergent lignin (ADL) and insoluble PA with and without addition of $\mathrm{Na}_{2} \mathrm{SO}_{3}$ to $\mathrm{Neutral}_{\text {Detergent. }}$ 
tion and decreases the amount of lignin and detergent insoluble $\mathrm{N}$.

There are 2 applications for the detergent system of analysis. First, NDF provides an estimate of the plant cell wall fractions. Acid detergent fiber estimates the cellulose and lignin, while ADL estimates lignin. For this application the presence of $\mathrm{PA} /$ protein complexes in the fiber residues interferes with the estimate of the plant cell wall and the addition of sodium sulfite to neutral detergent when analyzing plant species that contain PA may be advisable.

The second application of neutral detergent is to partition feed into fractions that reflect their bioavailability and nutritional uniformity. Protein in forages that do not contain PA are nutritionally uniform, have high true digestibility and are soluble in neutral detergent (Van Soest 1967). However, the true digestibility of protein is reduced in forages that contain PA and the protein is nutritionally non-uniform. This behavior of protein in forages containing PA is associated with an increase in NDIN, ADIN and ADL in both forages and feces. The recovery of $\mathrm{PA} /$ protein complexes in NDF reflects the nutritional non-uniformity of protein. The addition of sodium sulfite to neutral detergent will therefore give misleading results in relationship to the true digestibility of protein. On the other hand, the difference between fiber fractions that are prepared with and without the addition of sodium sulfite to neutraldetergent may estimate the actual amount of PA/protein complex associated with the NDF. Therefore, both analytical approaches may be used to study the effects of PA on protein digestion in forages.

\section{Management Implications}

A better understanding of the relationship between PA structure and function is necessary to manipulate PA in forages through breeding and selection or through genetic engineering. The interaction between PA and fiber analysis and digestion is an important component of this research. There is a fine line between the potentially positive effects of PA and their negative effects on intake, digestion and animal performance. The review by Waghorn et al. (1999) clearly outlines the magnitude of the problem and the research required. Topics include defining the chemical structure of PA in relationship to reactivity with proteins and enzymes, determining optimal concentrations and types of PA for ruminants, surveys of grasses, herbaceous plants, trees, browse shrubs and seed coats to determine PA concentration and reactivity. The effect of PA on the nutritive value and adaptation of rangeland species in the diets of ruminant herbivores is another important research topic. Products to overcome the negative effects of PA and related polyphenols on ruminant production on rangelands are sold in South Africa, Australia and Zimbabwe. However, the manipulation of range vegetation in relationship to PA content would be very difficult because many dominant woody species contain high levels of PA and related polyphenolic compounds.

\section{Literature Cited}

Barry, T. N. and S. J. Duncan. 1984. The role of condensed tannins in the nutritional value of Lotus pedunculatus 1. voluntary intake. Br. J. Nutr. 51:485-491.

Barry, T. N. and T. R. Manley. 1984. The role of condensed tannins in the nutritional value of Lotus pedunculatus for sheep 2. quantitative digestion of carbohydrates and protein. Br. J. Nutr. 51:493-504.

Barry, T. N., T. R. Manley, and S. J. Duncan. 1986. The role of condensed tannins in the nutritional value of Lotus pedunculatus for sheep. 4. sites of carbohydrate and protein digestion as influenced by dietary reactive tannin concentration. Br. J. Nutr. 55:123-137.

Bate-Smith, E. C. 1973. Tannins in herbaceous leguminosae. Phytochemistry 12:1809-1812.

Bate-Smith, E. C. 1975. Phytochemistry of proanthocyanidins. Phytochemistry 16: 1107-1113.

Beever, D. E., M. Gill and J. D. Sutton. 1989. Limits to animal production with high forage diets. J. Anim. Sci. 67(supp 1):298. (Abstr.).

Bravo, L., E. Mañas and F. Saura-Calixto. 1993. Dietary non-extractable condensed tannins as indigestible compounds: effects on faecal weight, and protein and fat excretion. J. Sci. Food Agr. 63:63-68.

Broadhurst, R. B. and W. T. Jones. 1978. Analysis of condensed tannins using acidified vanillin. J. Sci. Food Agr. 29:788-794.

Egan, A. R. and M. J. Ulyatt. 1980. Quantitative digestion of fresh herbage by sheep VI. utilization of nitrogen in five herbages. J. Agr. Sci. Camb. 94:47-56.

Feeny, P. P. and H. Bostock. 1968. Seasonal changes in the tannin content of oak leaves. Phytochemistry 7:871-880.

Foo, L. Y., W. T. Jones, L. J. Porter and V. M. Williams. 1982. Proanthocyanidin polymers from fodder legumes. Phytochemistry 21:933-935.
Giner-Chavez, B. I., P. J. Van Soest, J. B. Robertson, C. Lascano, J. D. Reed and A. N. Pell. 1997. A method for isolating condensed tannins from crude plant extracts with trivalent ytterbium. J. Sci. Food Agr. 74:359-368.

Hagerman, A. E. 1991. Tannin Analysis. Miami University, Oxford, Ohio, USA.

Hagerman, A. E. and L. G. Butler. 1981. The specificity of proanthocyanidin-protein interactions. J. of Biol. Chem. 256:4494-4497.

Hagerman, A. E., C. T. Robbins, Y. Weerasuriya, T. C. Wilson and $C$. McArthur. 1992. Tannin chemistry in relation to digestion. J. Range Manage. 54:57-62.

Harborne, J.B. 1993. Introduction to Ecological Biochemistry. Academic Press Limited, London. p. 318.

Harborne, J. B. 1994. The Flavonoids Advances in Research Since 1986. Chapman and Hall, London. P. 676.

Haslam, E. 1966. Chemistry of Vegetable Tannins. Academic Press, New York.

Haslam, E. 1989. Plant Polyphenols-Vegetable Tannins Revisited. Cambridge University Press, Cambridge, U.K.

Horvath, P. J. 1981. The nutritional and ecological significance of Acer-tannins and related polyphenols. M. S. Thesis, Cornell University, Ithaca, New York.

Jackson, F. S., T. N. Barry, C. Lascano, and B. Palmer. 1996. The extractable and bound condensed tannin content of leaves from tropical tree, shrub and forage legumes. J. Sci. Food Agr. 71:103-110.

Jimenez-Ramsey, L. M., J. C. Rogler, T. L. Housley, L. G. Butler and R. G. Elkin. 1994. Absorption and distribution of ${ }^{14} \mathrm{C}-$-labeled condensed tannins and related sorghum phenolics in chickens. J. Agr. Food Chem. 42:963-967.

Krueger, C. G., K. A. Albrecht, J. D. Reed, E. J. Bures, and V. N. Owens. 1999. Sodium sulfite effects on recovery and composition of detergent fiber and lignin from forage legumes varying in levels of proanthocyanidins. J. Sci. Food Agr. 79:1351-1356.

Martin, J. S. and M. M. Martin. 1982. Tannin assays in ecological studies: lack of correlation between phenolics, proanthocyanidins and protein-precipitating constituents in mature foliage of six oak species. Oecology 54:205-211.

McNabb, W. C., G. C. Waghorn, T. N. Barry and I. D. Shelton. 1993. The effect of condensed tannins in Lotus pedunculatus on the digestion and metabolism of methionine, cystine and inorganic sulphur in sheep. Br. J. Nutr. 70:647-661.

Mould, E. D. and C. T. Robbins. 1981. Evaluation of detergent analysis in estimating nutritional value of browse. J. Wildl. Manage. 45:937-947.

Mueller-Harvey, I. and A. B. McAllan. 1992. Tannins: their biochemistry and nutritional properties. Advances in Plant Cell Biochemistry and Biotechnology 1:151-217. 
Niezen, J.H., Waghorn, T.S., Charleston, W.A.G. and G.C. Waghorn. 1995. Growth and gastrointestinal nematode parasitism in lambs grazing either lucerne (Medicago sati$v a$ ) or sulla (Hedysarum coronarium) which contains condensed tannins. J. Agr. Sci. (Camb.) 125:281-289.

Oh, H. I., J. E. Hoff, G. S. Armstrong, and L. A. Haff. 1980. Hydrophobic interaction in tannin-protein complexes. J. Agr. Food Chem. 28:394-398.

Porter, L. J. 1994. Flavans and proanthocyanidins. In: J. B. Harborne (Ed.) The Flavonoids Advances in Research Since 1986. p. 23. Chapman and Hall, London.

Price, M. I., S. Van Scoyoc and L. G. Butler. 1978. A Critical evaluation of the vannillin as an assay for tannin in sorghum grain. J. Agr. Food Chem. 26:1214-1218.

Reed, J. D. 1986. Relationships among soluble phenolics, insoluble proanthocyanidins and fiber in East African browse species. J. Range Manage. 39:5-7.

Reed, J. D. 1987. Phenolics, fiber and fiber digestibility in bird resistant and non-bird resistant sorghum grain. J. Agr. Food Chem. 35:461-464.

Reed, J. D. 1995. Nutritional toxicology of tannins and related polyphenols in forage legumes. Invited Paper. Pharmacology/Toxicology Symposium on Toxic Legumes. J. Anim. Sci. 73:1516-1528.

Reed, J. D., H. Soller and A. Woodward. 1990. Fodder tree and straw diets for sheep: intake, growth, digestibility and the effects of phenolics on nitrogen utilisation. Anim. Feed Sci. Technol. 30:39-50.
Reed, J. D., P. J. Horvath, M. S. Allen and P. J. Van Soest. 1985. Gravimetric determination of soluble phenolics including tannins from leaves by precipitation with trivalent ytterbium. J. Sci. Food Agr. 36:255-261.

Reed, J. D., R. E. McDowell, P. J. Van Soest, and P. J. Horvath. 1982. Condensed tannins: a factor limiting the use of cassava forage. J. Sci. Food Agr. 33: 213-220.

Stafford, H. A. 1988. Proanthocyanidins and the lignin connection. Phytochemistry 27:1-6.

Stafford, H. A. 1990. Flavonoid Metabolism. CRC Press Inc., Boca Raton, Fla.

Stafford, H. A. and T. Y. Cheng. 1980. The procyanidins of Douglas fir seedlings, callus and cell suspension cultures derived from cotyledons. Phytochem. 19: 131-135.

Swain T. 1979. Tannins and lignins. In: G. A. Rosenthal and D. H. Janzen (Ed.) Herbivores, Their Interaction with Secondary Plant Metabolites. p 657. Academic Press, New York.

Tempel, A. S. 1982. Tannin measuring techniques: a review. J. Chem. Ecol. 8:1289-1298.

Terrill, T. H., A. M. Rowan, G. B. Douglas and T. N. Barry. 1992. Determination of extractable and bound condensed tannin concentrations in forage plants, protein concentrate meals and cereal grains. J. Sci. Food Agr. 58:321-329.

Terrill, T. H., G. C. Waghorn, D. J. Wooley, W. C. McNabb and T. N. Barry. 1994. Assay and digestion of ${ }^{14} \mathrm{C}$-labelled condensed tannins in the gastrointestinal tract of sheep. Br. J. Nutr. 72:467-477.
Van Soest, P. J. 1967. Development of a comprehensive system of feed analysis and its application to forages. J. Anim. Sci. 26:119-128.

Waghorn, G. C., J. D. Reed and L. R. Ndlovu. 1999. Condensed tannins and herbivore nutrition. Proceedings of the XVIII International Grassland Congress. Volume III-Invited Papers and Opening and Closing Sessions. P. 153. Association Management Centre, Calgary, Canada.

Waghorn, G. C., M. J. Ulyatt, A. John and M. T. Fisher. 1987. The effect of condensed tannins on the site of digestion of amino acids and other nutrients in sheep fed on Lotus corniculatus L. Br. J. Nutr. 57:115-126.

Waterman P. G., and S. Mole. 1994. Analysis of Phenolic Plant Metabolites. Blackwell Scientific Publications, Oxford, U.K.

Wiegand, R. O., J. D. Reed, A. N. Said and V. N. Ummuna. 1995. Proantocyanidins (condensed tannins) and the use of leaves from Sesbania sesban and Sesbania goetzei as protein supplements. Anim. Feed Sci. Technol. 54:175-192.

Yocum, F. 1995. Proanthocyanidins and polyphenols in ensiled forage legumes and nitrogen digestion by sheep. M. S. Thesis, University of Wisconsin-Madison, Madison, Wisc.

Yocum, F. D., and J. D. Reed. 1994. Proanthocyanidins and polyphenols in ensiled forage legumes and nitrogen digestion by sheep. J. Dairy Sci. 77 (Suppl.):385. (Abstr.). 